\title{
Às margens do Rio Araguaia... o Presídio Militar de Santa Leopoldina (Província de Goyaz, 1850-1959)
}

DOSSIER RIOS E CIDADES: ARAGUAIA

\section{Gercinair Silvério Gandara}

Docente da Universidade Estadual de Goiás [UEG]. Pós-Doutora em História [UFG]. Doutora em História Social [UnB]. Coordenadora Laboratório de História e Estudos Multidisciplinares em Ambientes [LHEMA/UEG]. Goiânia [GO] Brasil <gercinair.gandara@ueg.br>.

\section{Roberta Cristina Monteiro Pereira}

Historiadora pela Universidade Estadual de Goiás - Campus Uruaçu. Pesquisadora do Laboratório de História e Estudos Multidisciplinares em Ambientes. Uruaçu [GO] Brasil <roberttamonteirop@gmail.com>.

\section{Resumo}

Neste texto analisamos a implantação dos presídios militares às margens do rio Araguaia por meio dos Relatórios da Presidência da Província de Goiás que datam da segunda metade do século XIX. Buscamos entender como a construção do presídio Santa Leopoldina influenciou o povoamento a beira-rio Araguaia contribuindo, em especial, para o surgimento da cidade Aruanã.

\section{Palavras-chave}

História. Rios. Rio Araguaia. Presídios Militares. Goiás.

\section{On the banks of the Araguaia River... the Military Prison of Santa Leopoldina (Province of Goyaz, 1850-1959)}

\begin{abstract}
In this text we analyze the implantation of the military prisons on the banks of the Araguaia River through the Reports of the Presidency of the Goiás Province dated from the second half of the XIX century. We sought to understand how the construction of the Santa Leopoldina prison influenced the settlement along the Araguaia river area, especially contributing to the emergence of the Aruanã city.
\end{abstract}

\section{Keywords}

History. Rivers. Araguaia River. Military Prisions. State of Goias [Brazil]. 
1. Introdução

Quase no limpo, à altura de meio metro, de dentro da frágil cobertura, um filete de água clara abre seu caminho. É o rio Araguaia. Borges (2010).

A bacia Araguaia-Tocantins corresponde a $11 \%$ do território nacional brasileiro. ${ }^{1} 0$ rio Araguaia se une ao Tocantins em São João do Araguaia e juntos percorrem aproximadamente cerca de $935.000 \mathrm{~km}$ entre cidades e paisagens variadas. Produzem três zonas diferenciadas na paisagem, a zona amazônica utilizada como potencial hidrelétrico e mineral, a zona de transição da floresta para o cerrado usado como campo para criação de gado (pecuária extensiva) e a zona do cerrado com solo agricultável. Esta última zona é a que possui maior densidade demográfica. Ele nasce no Altiplano dos chapadões de Taquari e dos Baús que divide os estados de Goiás e Mato Grosso [Brasil]. Sua nascente encontra-se na Serra do Caiapó, próximo ao Parque Nacional das Emas no município de Mineiros, em Goiás. "A dois quilômetros do berço natural o Araguaia já corre forte, com cinco metros de largura e dois de profundidade, água cristalina e fria, banho lustral dos seus apaixonados" (Borges, 1987, p. 18). Faz di-

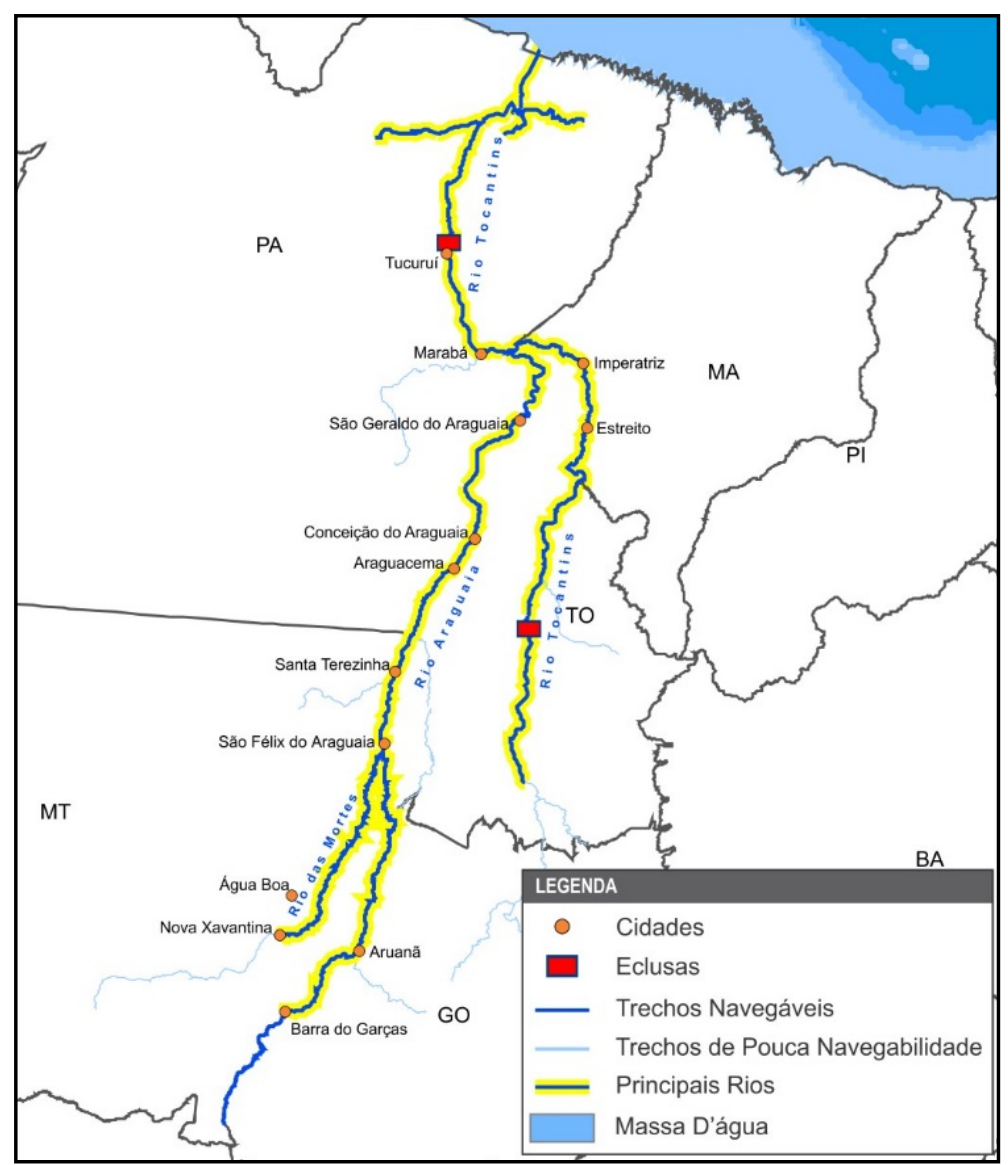

Figura 1. Bacia Hidrográfica dos rios Tocantins-Araguaia. Fonte: LabTrans/UFSC. visa natural entre quatro estados brasileiros: Mato Grosso e Goiás, Tocantins e Pará, Tocantins e Mato Grosso. Sua extensão total é de aproximadamente $2.114 \mathrm{~km}$. O rio Araguaia banha os estados de Goiás, Mato Grosso, Mato Grosso do Sul, Tocantins e Pará. Navegável em cerca de $1.818 \mathrm{~km}$ do seu percurso. Liga por meio da navegação o Centro Oeste ao Norte do país. É comumente dividido em três trechos, o do Alto Araguaia entre a foz e a cidade de Aruanã [GO] com1472 quilômetros de percurso e profundidade mínima de 1,0 metro. 0 trecho do Médio Araguaia se inicia em Aruanã [GO] estendendo até Barra do Garças [MT]. Tem 288 quilômetros de percurso e 0,9 de profundidade mínima. De Barra do Garças [MT] a cidade de Baliza [GO] num total de 58 quilômetros forma trecho do Baixo Araguaia com profundidade mínima de 0,8 metros. A navegação do rio Araguaia ocorre basicamente entre sua foz, no rio Tocantins e a cidade de Baliza [GO]. A navegação no Rio Araguaia ocorre apenas no período de cheias, entre os meses de dezembro e maio conforme levantamento realizado pela Agencia Nacional de Águas (ANTAQ 2013, p.35). De clima tropical com precipitações, a área de abrangência da bacia do Tocantins-Araguaia caracteriza, em quase sua totalidade, o bioma Cerrado.

As margens do rio Araguaia são marcadas por extensas matas pertencentes ao cerrado brasileiro. Nelas nascem, florescem e brotam frutos conhecidos pelo seu sabor exótico como o pequi, a mangaba o murici e a guariroba sendo estes últimos essenciais na cozinha típica goiana. Suas margens durante o século XIX eram habitadas por vários povos indígenas tais como os Karajás, os Javaés e

\footnotetext{
${ }^{1}$ De acordo com diagnóstico da Bacia Araguaia-Tocantins realizado e publicado pelo Ministério do Interior em convênio com OEA, 1982.
} 
os Xavantes dentre outras etnias. Nas margens do rio Araguaia viviam aproximadamente dez mil índios conforme Relatório do Presidente da Província de Goyás de 22/04/1861 de Dr. Manoel de Araújo e Mello enviado ao seu sucessor José Pereira de Alencastre em que relata,"desde a Ilha do Bananal até muito abaixo de Santa Maria, há por mais de dez mil índios da numerosa família Karajás, que subdivide com as dominações de Carajás, Carajahys, Javahés, Chambioás, e outros...”. Os índios Karajás "foram os primeiros povos a terem contatos com os bandeirantes", segundo Borges (2010, p.44).

Neste texto buscamos compreender a implantação dos presídios militares às margens do majestoso rio Araguaia por meio dos Relatórios da Presidência da Província de Goiás da segunda metade do século XIX. Buscamos perceber como a construção do presidio Santa Leopoldina influenciou o povoamento a beira-rio Araguaia contribuindo, em especial, para o surgimento da cidade Aruanã.

\section{Ber-ô-can... Araguaia... rio de muitos nomes e muitas lendas}

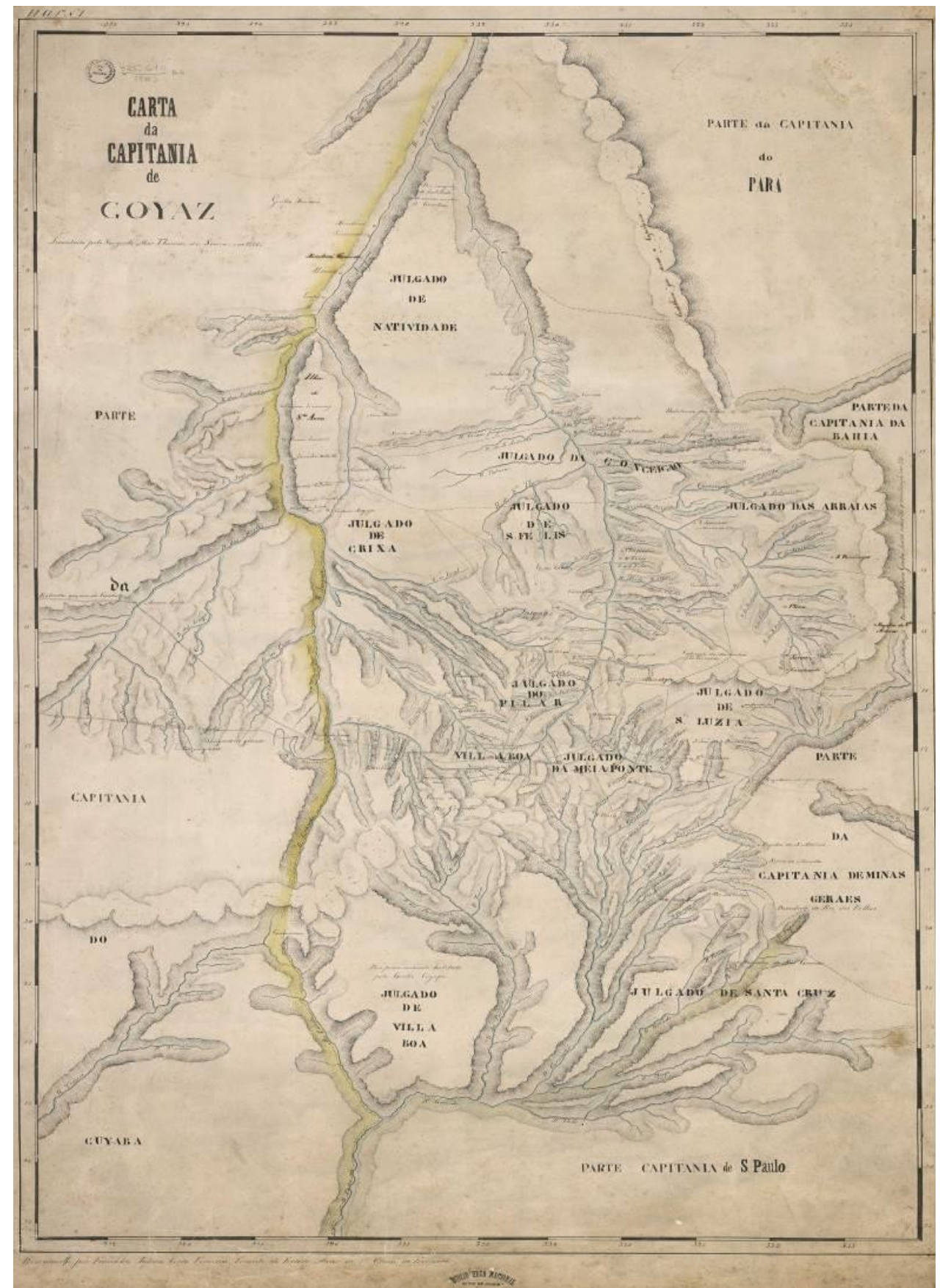

Figura 2. Carta da Capitania de Goiaz, Sargento Mor Thomas de Souza, 1778.

Fonte: Arquivo da Biblioteca Nacional. 
O rio Araguaia possui relevância econômica e política em toda região por onde percorre. Povoado de histórias e lendas é um rio de muitos nomes. Parafraseando Gandara (2010), se o nome do rio torna uma origem, e anuncia o destino do personagem histórico e os nomes enumeram sentidos deve-se deixar fluir os nomes, sentidos e os valores. Na Carta da Capitania de Goiaz levantada pelo Sargento Mor Thomas de Souza, em 1778, traz as denominações de Paraupava, rio Grande e rio Araguaya. 0 jesuíta Antônio de Araújo o denominou "Fermoso Braço". Antes, porém era chamado pelos Karajás de "Ber-ô-can", ou seja, rio Grande na língua deste povo. Já nos mapas do século XVIII se apresenta com a denominação de Paraupava. Chamaram-no também rio Araguaya que na língua tupi-guarani significa "rio das Araras", ou seja, aquelas que colorem o céu com suas penas vermelhas e azuis em uma valsa de extrema exuberância. Foram os Bandeirantes que assim o denominaram. Esta nomenclatura assim permaneceu mudando somente a grafia de "Araguaya" para rio Araguaia.

Os ribeirinhos/beiradeiros, visitantes e poetas reconhecem e enaltecem a beleza das águas araguaias. Trata-se de um rio lendário. Suas lendas carregam o poder de causar medo. Despertam curiosidades. Explicam as crenças e os costumes de um povo. Cada lenda tem sua própria história, sua razão para existir. Criadas com riqueza de detalhes deixam entrever a quão encantadora é a imaginação. Em verdade, as lendas são representações criadas a partir da imaginação para explicar determinados acontecimentos da sua história. De acordo com Chartier (1991) "a representação é o instrumento de um conhecimento mediato que faz ver um objeto ausente substituindo-lhe uma "imagem" capaz de repô-lo em memória e de 'pintá-lo' tal como é". Porém quando se refere à imaginação e a representação Chartier (1991) deixa claro que "a relação de representação é, desse modo, perturbada pela fraqueza da imaginação, que faz com que se tome o engodo pela verdade, que considera os signos visíveis como índices seguros de uma realidade que não o é". (Chartier, 1991, p. 185). As lendas do rio Araguaia são, em sua maioria, advindas do imaginário popular que transformadas em "verdades" faz com que muitas pessoas acreditem que há criaturas estranhas habitando as profundezas das águas araguaias. Para Castoriadis (1991) a questão do imaginário é repensada como sendo um mundo de significados estabelecidos durante a passagem do mundo real e um mundo social-histórico. Para Castoriadis (1991, p. 39), "o mundo das significações está cada vez mais instituído pelo real". Compreendemos as lendas como construções históricas das representações sociais, mas, também, como excelentes fontes históricas.

Os Karajás do Araguaia têm suas vidas marcadas por personagens lendários. Uma das mais famosas é a Lenda de Aruanã. Todos os anos os povos Karajás organizam o "Ritual do Aruanã" com danças e cantos homenageando o grande Aruanã, pai dos Karajás. Em verdade, Aruanã se trata de um espécime de peixe, encontrado nas águas doces do Rio Araguaia. Diz a lenda que Aruanã, filho de Aruá e primo dos lendários Arumanás vivia solitário e triste dentro das fundas águas do imenso Araguaia. Ele era um eterno enamorado da vida terrestre, particularmente da vida humana. Um dia, a poderosa Jururá-Açu, deusa das chuvas, do orvalho e irmã de Iara, impelida por sagrado desejo, chamou em meio as águas, os angás, os urumáças e seus filhos, para irem honrar o poderoso boto, senhor das águas, na funda onde habitava o deus marinho. Todos os seres das águas do volumoso Araguaia correram para o fundo do rio, a fim de erguerem suaves preces entre cantos e louvores. Somente Aruanã não conseguiu ir com a turba, mas tanto suplicou que sua prece acabou sendo ouvida. Aruanã exclamou: "pobre de mim, nas águas nasci, nas águas me criei, contudo já não tenho felicidade!". E colocando a cabeça fora da água, continuou, "ó pai Tupã, se a ti próprio te apraz, a felicidade de um pobre mortal, se próprio a mim, fazeme um ser humano e se, algum dia eu tenho que morrer não me deixe nessas águas, tire-me delas".

Tupã ouvindo as súplicas de Aruanã observou com olhos divinos e compadecidos o que passava ali nas margens do rio Araguaia. No aprazível e sagrado monte Ibiapaba ordenou "vá tu Pólo e satisfaz os desejos de Aruanã". As ordens do supremo foram obedecidas imediato, pois o "deus do vento" se aproximou do local em que estava o formoso peixe e tomando-o conduziu para o verde campo. Ali declarou, "és tu um valente guerreiro. Tupã mais do que dele esperavas!". Em seguida o deus dos ventos desapareceu. Ó maravilha! Ali estava um homem! Então vieram, por ordem do criador, as belas e divinas Karajás deusas da honra, do bem e da justiça e assim falaram: "Aruanã, peixe foste tu; Aruanã hás de chamar-te daqui para o futuro". 
Outra lenda conhecida por suas práticas no Vale do Araguaia é a do "Enterro" que se trata do enterro de bens materiais valiosos. Segundo esta lenda a pessoa escolhida recebe o "enterro" por meio dos sonhos. Vale ressaltar que o "Enterro" se trata de valores sepultados em determinada localidade. 0 falecido escolhe uma pessoa a qual destinará sua fortuna, ou seja, seu "enterro". Esse escolhido terá por meio do sonho detalhes da localidade onde está enterrada a fortuna, mas há algumas instruções que deverá seguir. Ele, o sortudo deverá ir sozinho fazer o desenterro, pois caso vá acompanhado, no lugar da fortuna encontrará objetos sem valor a exemplo de carvão. Ainda tem a ameaça do "capeta" segui-lo. Neste caso, a função do capeta é a de vigiar os pertences do falecido para que ninguém pegue e o espírito do falecido continue, em consequência, vagando no mundo dos vivos. ${ }^{2}$

Os poemas como as lendas contam histórias do rio Araguaia. Dentre tantos elegemos o poema de Hull de La Fuente intitulado "Margens do Araguaia", pois contempla o território em seu conjunto, ou seja, o vale, o rio, as matas, a fauna, a flora e o folclore das gentes ribeirinhas 0 poeta recorda sua vivência com a beleza da fauna e flora quando versa, [...]

"Revendo as velhas palmeiras / Onde os sabiás cantavam / As flores das quaresmeiras / Que de mel alimentavam /Os colibris e abelhas / Que nessas margens habitavam / E as frondosas gameleiras / De cujos galhos eu saltava. Na manhã ensolarada. / Em tuas margens verdejantes. / Contemplei maravilhada. / As águas doces passantes".

Neste verso a poetisa contemplou as águas araguaias e suas matas verdejantes retratadas com a exuberância do nascer do sol compondo e embelezando a paisagem Araguaia. Noutros trechos do poema ressaltou a grandeza das praias banhadas pelo rio Araguaia.

\section{"Revendo-te ó Araguaia. / A emoção me domina. / A beleza desta praia. / Simplesmente} me fascina".

La Fuente ressaltou o turismo que atrai o Araguaia com suas praias.

"Praia de brancas areias / Que atraem multidões / Onde vivem as sereias / Que arrebatam corações / Águas mornas do meu rio / Deste meu Brasil querido / Onde a natureza em cio / Canta o amor a ser vivido".

São tantas praias ali no Araguaia! tantas a perder de vista, dentre elas, a praia do Foguete em São Miguel do Araguaia e a praia do Araguaia em Aruanã, ambas em Goiás que são muito procuradas durante os meses de junho e julho, período da temporada de férias.

A poetisa versou, também, sobre as "brincadeiras de crianças" que fazem parte da cultura popular dos ribeirinhos como "o pega-pega e a mulher do padre" que foram adaptadas para serem realizadas nas margens e águas do rio Araguaia.

"Assaltam-me as lembranças / Daqueles tempos de então / Quando com outras crianças / Com muita satisfação / Bem afoita eu mergulhava / Pra sentir a emoção / E saber quem mais nadava / Na simples competição".

Versou, também, sobre o folclore. 0 vale araguaiano é mesmo marcado por um conjunto dessas manifestações populares constituídas por lendas, mitos, brincadeiras e festas que foram/são transmitidas de geração em geração.

"Daqui vejo a velha serra / Onde morava o gigante / Que estremecia a terra / Com seu jeito apavorante / Dele não restou lembrança / No folclore popular / Era conto pra criança / Diplomada em sonhar".

Dedicou duas estrofes a súplicas para que as lendas não desapareçam. A título de exemplo, como forma de imortalizar a histórias do folclore popular brasileiro, poetizou a quase esquecida lenda da boiúna, uma cobra de fogo que protege a fauna e a flora.

\footnotetext{
${ }^{2}$ Há outras versões desta lenda contada pelos ribeirinhos do Araguaia. www.rosanevolpatto.tdr.br
} 
"Da boiúna, ou cobra grande / Ninguém mais se lembra dela / Deve ter sido pescada / E cozida na panela / Pelo gigante da serra / Que tava de olho nela / Por que vivia em guerra / Causando muitas mazelas / Até o boto galante / Virou banquinho de praça / Lá no porto do Baé / Da velha Barra do Garça / Reaja boto, reaja / Seu lugar não é ali / Volte para o Araguaia / Que está passando aqui".

Noutros versos, a poetisa saudosa dos folguedos retorna ao seu passado enquanto criança e do quanto era bom banhar e brincar no rio de águas puras e correntes.

\begin{abstract}
"Este é o Araguaia / Onde em criança eu nadava / No porto de lá da chácara / Onde com meus pais morava / Naquele tempo eu não tinha / O temor que sinto agora / De banhar-me nessas águas / Só a ideia me apavora / Perdoa-me Araguaia, vou deixar-te, vou embora".
\end{abstract}

\title{
3. Os presídios militares na linha do rio Araguaia
}

Para falar sobre a implantação e a construção dos presídios militares as margens do rio Araguaia e, consequentemente, o surgimento das cidades ribeirinhas, torna-se necessário entender o contexto anterior a essa implantação. Palacin (1986) enfatiza que durante o século XVII, as primeiras bandeiras preferiam adentrar o interior de Goiás por caminhos fluviais, seguindo o curso dos rios Paranaíba, Tocantins e Araguaia. Tal escolha se deveu a falta de estradas e de animais que facilitasse o transporte terrestre. Depois de 1630, com a obtenção de animais, as bandeiras optaram pelas viagens por terra percorrendo todo território goiano em busca de ouro e dos gentios.

As primeiras expedições em direção ao Vale do rio Araguaia foram organizadas, em São Paulo e Bahia, cujo objetivo era explorar o interior do Brasil e buscar riquezas minerais. As bandeiras organizadas em São Paulo saíam à procura de índios, chegando ao extremo norte da província de Goyaz. Pe. Palacin (1986) nos advertiu de que a primeira bandeira, que partindo de São Paulo possivelmente chegou até os sertões de Goiás no leste do Tocantins foi a de Antônio Macedo e Domingos Luis Grau (1590-1593). Depois se seguiu a de Domingos Rodrigues (1596-1600) que desceu até a confluência do Tocantins com o Araguaia Estas bandeiras se tratavam de expedições organizadas militarmente e não tinham o intuito de se fixar na região. Com interesses comerciais em comum buscava, em sua maioria, índios para servir como mão-de-obra que para este fim cada participante disponibilizava uma parcela de capital e certo número de escravos. Somente em 1722, sairia uma bandeira com o intuito de povoar o centro-oeste do Brasil, a de Bartolomeu Bueno, o Anhanguera que demonstrou interesse em se fixar nessas regiões ${ }^{3}$. Houve, também, uma intensa vinda de missionários, que se dirigiam às comunidades indígenas com a política de formação de aldeamentos indígenas. Esta política foi adotada em Goiás durante a segunda metade do séc. XVIII com duas finalidades, ou seja, a formação de núcleos que se destinava a promover a catequização dos indígenas e o intuito de transformar os indígenas em mão de obra.

A ordem dos Jesuítas que penetrou o sertão araguaiano enfrentou inúmeras dificuldades, pois a empreitada de pacificar os indígenas era desprovida de quaisquer recursos. Os primeiros contatos com os indígenas foram cercados de desconfiança que os recebiam quase sempre a flechadas e golpes. Além da animosidade deparada com os indígenas havia os perigos da mata que segundo Borges dificultavam as viagens dos jesuítas e missionários.

Também não conheciam os padres o local, as matas ribeirinhas ou os igarapés, os lagos traiçoeiros e os pantanais inesperados, os caminhos e batidos, a picada de fogo da arraia, a rabanada fraturante dos jacarés, as arremetidas das onças sorrateiras, a convivência com febres palustres, o veneno do timbó, a queimada das urtigas [...] (Borges, 2010, p. 62).

Contudo ao chegarem em seu destino iniciavam a construção da primeira capela e da primeira escola para catequização dos indígenas e o cultivo de produtos como a mandioca e o milho entre outros cereais que ajudariam na alimentação. Também penetraram estas plagas e águas araguaianas os "amantes do Araguaia", como os chamam Durval Borges (2010). Estes vinham em

\footnotetext{
${ }^{3}$ Ver Luis Palacín e Maria Augusta Sant’anna Moraes. História de Goiás (1722-1972). Goiânia: Ed. UCG, 1989.
} 
busca dos mistérios e/ou movidos pela paixão ou pela imaginação para escrever livros e diários. Os comerciantes também se destacam, pois desde a abertura de caminhos no sertão goiano estiveram por estas terras. Há, ainda, incontáveis heróis anônimos que desceram o rio em busca de méritos. Dessas gentes advêm lendas, poemas e músicas que ressaltam o rio Araguaia e suas belezas. Há muitas destas histórias escritas em crônicas, poesias, prosas, versos e nos relatos do passado e do presente.

O governo imperial por meio de medidas governamentais incentivou a agricultura, o comércio e a navegação dos rios brasileiros. Entre algumas resoluções criadas pelo governo havia as que propunha a isenção dos dízimos em um tempo de 10 anos aos lavradores que cultivassem as margens dos rios Araguaia, Tocantins e Maranhão. Joaquim Teotônio Segurado em Memória Econômica e Política sobre o Comércio Ativo da Capitania de Goiás, 1806 endossou dizendo que [...]

[...] "três, ou quatro feitorias no Araguaia e duas no Maranhão, juntas com o privilégio de não pagarem Dízimos pelo espaço de 10 annoz as pessoas, que se estabeleceram nas margens dos ditos rios, afiançarão aos navegantes tanto sua subsistência, como a sua segurança da parte dos Gentios" (Segurado, 1806).

Propunha, também, a catequização dos índios para transformar em mão de obra na lavoura e a criação de presídios militares as margens dos rios, com o intuito de proteger o comércio e auxiliar a navegação. Para Alencastre (1963) [...]

[...] "tais medidas devem sem dúvida resultar as maiores vantagens a essa capitania, facilitando as relações comerciais, promovendo a riqueza e a segurança desses povos".

Tais tentativas até as primeiras décadas do século XIX não retiraram o marasmo em que a província goiana jazia. Vale ressaltar que o estado de marasmo não era uma característica singular da Província de Goyaz, pois se via este estado de coisas em todo a Colônia acarretada pelas guerras napoleônicas. 0 ouvidor de Goiás, Teotônio Segurado em 1806 elaborou um documento para demonstrar a insatisfação que a capitania goiana se encontrava, denominado "Memória Econômica Política sobre o Comercio Ativo da Capitania de Goiás" no qual descreve que a capitania era isolada e limitava-se a agricultura cujo comercio era interno e fraco. A agricultura vivia em um longo tempo de angústia porque [...]

[...] ou as colheitas são abundantes, ou escassas: no primeiro caso os agricultores não conseguirão as produções do seu trabalho, preços proporcionados à despesa da agricultura; no segundo os artífices e negociantes apenas poderão conseguir os necessários mantimentos para subsistência; uma grande parte do povo padecerá, e muitos gados perecerão de fome [...] (Segurado, 1806).

Para Teotônio Segurado um dos fatores que impossibilitava o desenvolvimento da capitania era a falta de um comercio ativo, pois Goiás não exportava e dependia do comercio externo, cujos produtos vindos de outras capitanias, com preço exorbitante, levava a população a comprar "fiado". Para ele, essa compra sem capital em mãos causou a ruína da capitania.

A Capitania nada exportava; o seu comércio externo era absolutamente passivo, os gêneros da Europa vinham em bestas do Rio de Janeiro, ou Bahia pelo espaço de 300 léguas, chegavam caríssimos; os negociantes vendiam tudo fiado: daí a execuções, daí a total ruína da Capitania [...] (Segurado, 1806).

De acordo com Carvalho (2008), Teotônio Segurado sugeriu "a comercialização com a província do Pará pelas vias fluviais e relacionou alguns produtos do comercio ativo da província fixando preços para comercializar com outras capitanias beira-mar". Já Dalisia Doles (1971), afirmou que era preciso a província de Goiás estabelecer o comércio com o Pará, para sanar os problemas adquiridos com o esgotamento das minas.

A situação econômica de Goiás é grave em consequência do gradativo esgotamento das minas. A ligação e o restabelecimento do comércio Goiás-Pará poderiam vir a ser a solução

(c) Labor \& Engenho, Campinas [SP] Brasil, v.11, n.2, p.146-164, abr./jun. 2017. 
para êsse e muitos outros problemas. As relações comerciais passam a interessar aos governos das duas capitanias', principalmente as do Pará, porto de mar e centro distribuidor dos produtos europeus. (Doles, 1971, p. 254).

O governo de Goiás via uma oportunidade na comercialização com o governo do Pará, pois era um caminho para acesso ao litoral e, consequentemente, um acesso aos produtos europeus com baixo custo. Destarte, a navegação dos dois principais rios, Araguaia e Tocantins foram estimulados para que os negócios entre as capitanias de Goiás e do Pará prosperassem.

No Brasil, a falta de estradas fez com que os governantes optassem pelos caminhos fluviais. De fato, o governo imperial propôs um melhoramento nas vias navegáveis do Brasil a fim de estabelecer comunicação e aliança no comércio entre o centro do país e o litoral. Parafraseando Gandara em "Rio Parnaíba... Cidades-beira (1850-1950)", durante os governos do Império (1822-1889), e de igual forma após a proclamação da República elaboraram-se planos ambiciosos de transportes para o Brasil tendo como principal propósito a interligação das distantes e isoladas províncias com vistas à constituição de uma nação-estado verdadeiramente unificada. A promoção e o desenvolvimento dos transportes constituíam, assim, um fator crucial para o alargamento da base econômica do país. Permitiria o povoamento em áreas de baixa densidade demográfica e possibilitaria a descoberta e o desenvolvimento de novos recursos. A ideia básica era mostrar a importância da integração das várias regiões brasileiras.

Neste período a rede fluvial brasileira tornou-se objeto das atenções governamentais, obra a ser realizada paulatina e sistematicamente, afim de que se facilitasse e incrementasse a navegação interior e se facultasse transporte eficiente, barato e rápido. Efetivamente, havia no país um anseio em dotá-lo de um sistema de vias de comunicação fluída. A partir de então surgiram diversos e ambiciosos planos, projetos e tentativas de se construir uma infraestrutura dos transportes no país, entre eles o fluvial, com objetivos integracionistas de desenvolvimento socioeconômico e de modernização da economia nacional.

A título de exemplo, dentre as propostas, vale ressaltar o estudo do engenheiro militar Eduardo José de Moraes, intitulado "Navegação Interior no Brasil"4, apresentado ao governo imperial em 1869. Este continha ambicioso projeto de aproveitamento de vários rios brasileiros destacando as enormes potencialidades das bacias hidrográficas brasileiras, prevendo a implantação de uma ampla rede de navegação fluvial que "facilitaria as comunicações dos mais remotos pontos do país entre si [...]" (Brasil, 1978, p. 4); e o de Honório Bicalho, engenheiro da Diretoria de Obras Públicas do Império que reuniu, em relatório de 1881, os estudos e sugestões dos primeiros decênios do século XIX. Pleiteando um plano de viação nacional e admitindo as ideias centrais de seus precursores em relação ao aproveitamento das "estradas móveis" enfatizou que, [...]

[...] o primeiro meio que mais naturalmente se apresenta para vencer as grandes distâncias, que quase isolam as diversas províncias do império, é utilizar a navegabilidade natural e aperfeiçoada dos rios e ligá-los por meio de estradas de ferro convenientemente traçadas em posição das grandes linhas futuras, e formar assim as primeiras linhas gerais mistas de viação a vapor, que atuem como grandes artérias para levar o movimento da vida intelectual e o impulso do progresso das capitais a todos os pontos do gigantesco corpo do Brasil (Bicalho, 1881).

De fato, os rios nos discursos dos presidentes da Província tinham representação de integração e de "fronteira" a ser conquistada e ocupada. Oliveira (2008, p. 60) afirma que, "os rios passaram a ser vistos, principalmente no discurso dos Presidentes da Província, como uma nova fronteira a ser conquistada e ocupada sistematicamente, para possibilitar uma ligação com o litoral". Enfatiza que seria "uma saída em duplo sentido, como caminho e como meio de salvar a Província do

\footnotetext{
${ }^{4}$ Este estudo ficou conhecido como Plano Moraes. Propunha a interligação de todas as bacias hidrográficas do país. A do rio Amazonas e seus afluentes, no norte, com a do rio da Prata, no sul, através dos rios Paraná, Paraguai e Uruguai, e a desses rios com a do rio São Francisco, no sudeste e nordeste, e, finalmente, a ligação desta última bacia com a do rio Parnaíba e seus afluentes, na porção mais ocidental da região nordeste. Ver BRASIL. Câmara dos Deputados. Mensagens presidenciais, 1890-1910. — Brasília: 1978. (Série Documentos Parlamentares, n. 9).
} 
marasmo em que se encontrava". Teotônio Segurado em seus escritos destacou uma série objetivos que permeavam do econômico ao demográfico para que houvesse a expansão da fronteira e a implantação dos presídios militares. Para ele fazia-se necessário povoar as margens dos rios Araguaia e Tocantins. Para tanto apresentou alguns objetivos, que para ele, após concluídos tanto o comércio interno quanto o externo viriam a se desenvolver. São eles:

1. Demográfico - através da expansão do povoamento nas margens dos principais rios de comunicação, veria a prosperidade do comercio;

2. Objetos morais - pretendiam-se transferir os marginalizados para as colônias militares e dar a eles trabalhos;

3. Objetivo militar - defender o território; e naturalmente,

4. Econômico - veria o comercio interno e externo desenvolvido. (Carvalho, 2008; p. 87).

Teotônio Segurado enviou ao governador D. Francisco Mascarenhas um documento no qual retratava a real situação da província goiana e juntamente as medidas que viriam a "salvá-la". 0 então governador, em abril de 1806, quando o recebeu encaminhou diretamente a Dom João VI. Mas, somente em setembro de 1811, com a elaboração da Carta Régia é que, talvez, tais objetivos fossem alcançados.

Quanto ao povoamento de Goiás ${ }^{5}$ se deu instável e de forma irregular, sem nenhuma ordem devido ao rumo em que a mineração ia se fortificando. As zonas inicialmente povoadas foram as do "centro-sul" e a "região do Tocantins". De acordo com Palacin (1986), "o norte da Capitania de Goiazes que engloba o sul e o sudoeste e todo o percurso em que o rio Araguaia banha não houve nenhuma povoação nos primeiros anos da província". A ocupação dessas regiões se daria efetivamente entres os séculos XIX e XX com a implantação da navegação a vapor no rio Araguaia na segunda metade do século XIX.

Quando falamos da navegação a vapor no rio Araguaia se nos remete, obrigatoriamente, ao Dr. José Vieira do Couto Magalhães, defensor do melhoramento da navegação fluvial. Foi em 1868 que se inaugurou a navegação a vapor no rio Araguaia com a presença deste pioneiro da navegação fluvial no Brasil Central. Ele acreditava que a navegação a vapor contribuiria para o desenvolvimento da província de Goiás. Couto Magalhães percorreu o rio Araguaia, juntamente com o desembargador João Bonifácio dando assim os primeiros passos para a navegação neste rio. Desta viagem elaborou um relatório datado de 1o de setembro de 1870 em que se referia à inauguração da navegação a vapor no rio Araguaia. Nele o desembargador cita o transporte por terra de um barco a vapor que fora desmontado em Mato Grosso até a colônia de Itacayú onde fora remontado e/ou reconstruído. Em seguida foi posto a navegar nas águas araguaias no trajeto de Itacaiu [GO] até a região do presidio de Santa Leopoldina.

Couto Magalhães, mandando desarmar um pequeno vapor de Mato Grosso, o fez transportar por terra até a colônia de Itacayú, no alto Araguaia, onde foi de novo reconstruído, e, descendo águas abaixo, tendo a seu bordo o referido presidente, que pretendia seguir para o Rio de Janeiro, foi estacionar junto ao mencionado Presídio de Santa Leopoldina, tomando no ato da inauguração do nome Araguaya (Trecho do Relatório da presidência Dr. desembargador João Bonifácio Gomes Siqueira - 1ํ de setembro de 1870).

Couto Magalhães determinado em incrementar a navegação do rio e o povoamento das margens do Araguaia, se dirigiu ao rio Araguaia para conhecer a sua viabilidade e as condições que apresentava para que a povoação ocorresse. Parafraseando Doles (1973) Couto Magalhães partiu no dia 25 de setembro de 1863 do porto do rio Manuel percorrendo quase todo o rio Araguaia. 0 mesmo já havia solicitado em julho do mesmo ano ao engenheiro Ernesto Vallée um estudo mais preciso, observando as possibilidades e as vantagens da navegação do rio Araguaia. Tal estudo

\footnotetext{
${ }^{5}$ O povoamento de Goiás se deu a partir de 1722, com a descoberta de ouro na região do rio Vermelho. Sant'ana foi o primeiro arraial de Goiás. Assumiu a categoria de Vila denominada Vila Boa. E mais tarde tornou-se a primeira Capital de Goiás. Os arraiais que surgiram após a fundação de Sant'ana, seguiam, também, os cursos dos rios devido o processo da mineração. Com a diminuição do processo da mineração, o governo português passou a promover e incentivar a agricultura em Goiás por meio de tentativas governamentais para que a província prosperasse.
} 
fez com que Vallée conhecesse as vias navegáveis dos principais rios da província de Goiás. Vallée concluiu que essa imensa linha fluvial que atravessa o Brasil de norte a sul, [...]

[...] cujo desenvolvimento é de 401 11/4 léguas (2.648km e 250m), apresenta 239 léguas

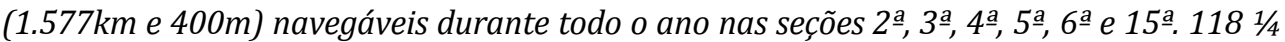
léguas das seções 1aㅗ 7ạ, 9a e 10ạ são navegáveis igualmente a vapor durante seis meses de dezembro a maio o que eleva a $3541 / 4$ léguas $(2.338 \mathrm{~km}$ e $050 \mathrm{~m})$ navegáveis a vapor, considerando a navegação nos meses de dezembro a maio. 44 léguas (290km e 400m) nas seções $8^{a}, 11^{a}, 12^{a}$, $13^{a}$ e $14^{a}$ são obstruídas pela natureza e só permitem a passagem de canoas e no tempo das secas. Para obter-se a franca navegabilidade fazia-se necessária a remoção dos obstáculos que existiam nas últimas seções consideradas (Jornal da Província de Goyáz, anno II, no 45 de 5 de novembro de 1870).

Em janeiro de 1864, depois de feito todo o estudo, Vallée encaminha ao presidente suas considerações finais acerca do rio Araguaia (ver Quadro 1). Conforme o estudo desse engenheiro apresentado no Jornal da Província de Goyaz (1870) a navegabilidade do Araguaia durante todo o ano se restringia ao trecho da foz do rio Vermelho ou do Presídio de Santa Leopoldina até o local do antigo presídio de Santa Maria era navegável sem restrições e daí até o presídio de São João das duas Barras apresentava dificuldades para navegação entre os meses de dezembro a maio. Nesses últimos trechos, ou seja, do antigo presídio de Santa Maria ao presídio de São João das Duas Barras a navegação só era possibilitada no período das enchentes. Lembrando que da correnteza de São Miguel à Cachoeira Grande só permitia a passagem de canoas no período das secas. Este é um trecho encachoeirado e de fortes correntezas daí precisaria de serviços técnicos de limpeza para fluir a navegação. Como se vê a navegação do rio Araguaia necessitava de um aparelhamento técnico para que pudesse se tornar concreta.

Quadro 1. Planilha do resultado dos estudos de Vallée apresentado a Couto Magalhães.

Fonte: Jornal Província de Goyaz, 1870.

\begin{tabular}{|c|c|c|c|c|}
\hline RIOS & ESTAÇŌES & PONTOS & $\begin{array}{c}\text { CONDIÇÖES DE } \\
\text { NAVEGABIILIDADE }\end{array}$ & $\begin{array}{l}\text { LEGGA } \\
\text { S }\end{array}$ \\
\hline $\begin{array}{c}\text { Rio } \\
\text { Vermelho }\end{array}$ & $1^{\circ}$. & Do ponto do travessão a foz & $\begin{array}{l}\text { Navegáivel c/ restriçóes (de } \\
\text { dezembro a maio) }\end{array}$ & $\overline{32}$ \\
\hline Araguaia & $2^{\circ}$ & $\begin{array}{l}\text { Da foz do Rio Vermelho ou } \\
\text { do Presidio de Santa } \\
\text { Leopoldina até o porto da } \\
\text { Piedade }\end{array}$ & $\begin{array}{l}\text { Navegável sem restriçóes } \\
\text { (durante o ano todo) }\end{array}$ & $26^{1 / 2}$ \\
\hline$=$ & $3^{\circ}$ & $\begin{array}{l}\text { Do porto da Piedade á ponta } \\
\text { do sul da illha do Bananal }\end{array}$ & $\begin{array}{l}\text { Navegável sem restriçōes } \\
\text { (durante o ano todo) }\end{array}$ & $164 / 4$ \\
\hline$=$ & $4^{\circ}$ & $\begin{array}{l}\text { Da ponta sul a ponta norte da } \\
\text { illa do Bananal }\end{array}$ & $\begin{array}{l}\text { Navegável sem restriçóes } \\
\text { (durante o ano todo) }\end{array}$ & $831 / 2$ \\
\hline$=$ & $5^{\circ}$. & $\begin{array}{l}\text { Da ponta norte da itha do } \\
\text { Bananal ao presidio de } \mathrm{S} \text {. } \\
\text { Maria }\end{array}$ & $\begin{array}{l}\text { Navegável sem restriçóes } \\
\text { (durante o ano todo) }\end{array}$ & $27 \%$ \\
\hline - & $6^{\circ}$. & $\begin{array}{l}\text { Do presídio de S. Maria ao } \\
\text { antigo presídio do mesmo } \\
\text { nome }\end{array}$ & $\begin{array}{l}\text { Navegável sem restriçóes } \\
\text { (durante o ano todo) }\end{array}$ & $10 \frac{1 / 2}{2}$ \\
\hline$=$ & $7^{\circ}$ & $\begin{array}{l}\text { Do antigo presidio de S. } \\
\text { Maria ì correnteza de Stio } \\
\text { Miguel }\end{array}$ & $\begin{array}{l}\text { Navegável of restriçóes (de } \\
\text { dezembro a maio) }\end{array}$ & $53 \%$ \\
\hline$=$ & $8^{\circ}$ & $\begin{array}{l}\text { Da correnteza de Sta Miguel } \\
\text { à Cachoeira Grande }\end{array}$ & $\begin{array}{l}\text { Só permite a passagem de } \\
\text { canoas e no tempo das secas }\end{array}$ & 11 \\
\hline - & $9^{\circ}$ & $\begin{array}{l}\text { Da Cachoeira Grande ao } \\
\text { presidio de São João das } \\
\text { Duas Barras }\end{array}$ & $\begin{array}{l}\text { Navegável of restriçóes (de } \\
\text { dezembro a maio) }\end{array}$ & $29 \%$ \\
\hline $\begin{array}{c}\text { Rio } \\
\text { Tocantins }\end{array}$ & $10^{\circ}$. & $\begin{array}{l}\text { Do presídio de Săo Joâo das } \\
\text { Duas Barras ao Bacabal }\end{array}$ & $\begin{array}{l}\text { Navegável } d \text { restriçōes (de } \\
\text { dezembro a maio) }\end{array}$ & 3 \\
\hline - & $11^{\circ}$. & $\begin{array}{l}\text { Do Bacabal ì entrada de } \\
\text { Taury }\end{array}$ & $\begin{array}{l}\text { Só permite a passagem de } \\
\text { canoas e no tempo das secas }\end{array}$ & 12 \\
\hline - & $12^{\circ}$. & Correnteza de Taury & $\begin{array}{l}\text { Só permite a passagem de } \\
\text { canoas e no tempo das secas }\end{array}$ & \\
\hline- & $13^{\circ}$. & $\begin{array}{l}\text { Da Cauda de Taury ao } \\
\text { Portinho }\end{array}$ & $\begin{array}{l}\text { Só permite a passagem de } \\
\text { canoas e no tempo das secas }\end{array}$ & $\overline{4}$ \\
\hline$=$ & $\overline{14^{\circ}}$. & Do Portinho a Arroios & $\begin{array}{l}\text { Só permite a passagem de } \\
\text { canoas e no tempo das secas }\end{array}$ & $81 / 2$ \\
\hline$=$ & $15^{\circ}$. & De Arroios à Belém & $\begin{array}{l}\text { Navegável sem restriçoes } \\
\text { (durante o ano todo) }\end{array}$ & 74 \\
\hline
\end{tabular}




\section{A implantação dos presídios militares as margens do rio Araguaia}

Os presídios militares foram implantados as margens do rio Araguaia a partir do decreto no 750 de 02/01/1851. Os presídios era "um misto de colônia agrícola e estabelecimento penal", segundo Rocha (1998, p. 71). Pertencia ao presidio militar, de acordo com o artigo 25 do decreto $\mathrm{n}^{\mathrm{o}}$ 750 , uma cadeia pública, uma capela, um estaleiro e residências para religiosos, comandantes e moradores. Em verdade, a construção destes presídios garantiria a defesa do território e promoveria a comercialização dos produtos trazidos pelos comerciantes, o que consequentemente, beneficiaria a coroa portuguesa. Mas, tinham, ainda, outras finalidades como atrair um número elevado de colonos para as margens do rio Araguaia.

\section{O Relatório do Presidente da Província de Goiás de 1852 ratificava que [...]}

[...] "a função primordial do presidio era o de atrahir povoações para esses vastos terrenos e proteger a navegação fluvial entre esta e a Província do Pará pelo Araguaia" (Memorias Goianas 5, 1996, p.184).

Devemos ficar atentos à definição de presidio no século XIX, pois este termo era utilizado segundo Carvalho (2010), "como conquista de território e expansão de fronteira, parte do processo de povoamento, defesa e especialização agrícola construído oficialmente e sob o controle do governo". Segundo o relatório de Alencastre (1861) ficou decidido entre os regulamentos, o procedimento a ser tomado pelos presídios em auxiliar na catequização dos índios e torná-los mão de obra nos mesmos. A relação entre presídios e os índios locais era conturbada. Os indígenas evitavam ao máximo a implantação desses presídios ou o contato com a população que migrava para as margens do rio Araguaia. Por outro lado, o governo implantava medidas para evitar e controlar os ataques indígenas.

Com o fim de proteger a navegação dos rios Tocantins e Araguaya, e defender a população do norte das agressões dos selvagens que habitam as margens destes dous rios e de seus tributários, fundar-se-ão os cinco presídios militares que actualmente existem, três na linha do Tocantins e dous na do rio Araguaya. Se não posso crer na utilidade de um outro, pela posição em que se achão collocados, absolutamente falando, a creação desses núcleos coloniais não pode deixar de ser considerada de grandes vantagens. Deve-se concluir pela necessidade de outros estabelecimentos desse gênero no prolongamento das margens dessas grandes artérias, que, por assim dizer, contêm em si a história do futuro progresso desta bela porção do Império. Desde que vários pontos da província são ameaçados frequentemente pelos selvagens sem que dos presídios existentes possão partir socorros $e$ previdências a tempo; desde que seus habitantes são obrigados a lançar mão de meios próprios, e muitas vezes de natureza violentos, para expellirem os ataques dos índios, resultando da violência desses meios o crescer cada vez mais o seu ódio contra nós, está visto que os recursos de defesa devem ser augmentados, e que os presídios existentes não são uma garantia bastante (Trecho do Relatório apresentado à Assembléia Legislativa Provincial de Goyaz na sessão ordinária de 1861 pelo presidente José Martins Pereira de Alencastre).

A localização dos presídios e fortes se concentravam em lugares estratégicos nas passagens da rede fluvial, onde serviriam como pontos de comunicação. Carvalho $(2008$, p. 48) afirma que essas fortificações eram "situadas nos principais lugares de comunicação, as fortificações constituíram assim verdadeiros marcos de fronteira, tendo ainda função adicional de potencializar focos de povoamento em diversas partes do Brasil colonial e imperial". Na segunda metade do século XIX, com a política de implantação dos presídios militares como necessidade para fortalecer a navegação a vapor intensificou-se a construção dos fortes e presídios as margens da linha do rio Araguaia.

Na Província de Goiás foram construídos vinte e um (21) presídios as margens dos seus dois principais rios, Araguaia e Tocantins. Na linha/margens do rio Araguaia durante a segunda metade do século XIX foram construídos sete presídios, sendo eles, o de Santa Isabel, Leopoldina, Januária, Santa Maria, Monte Alegre, Jurupensen e por fim São José dos Martírios. 


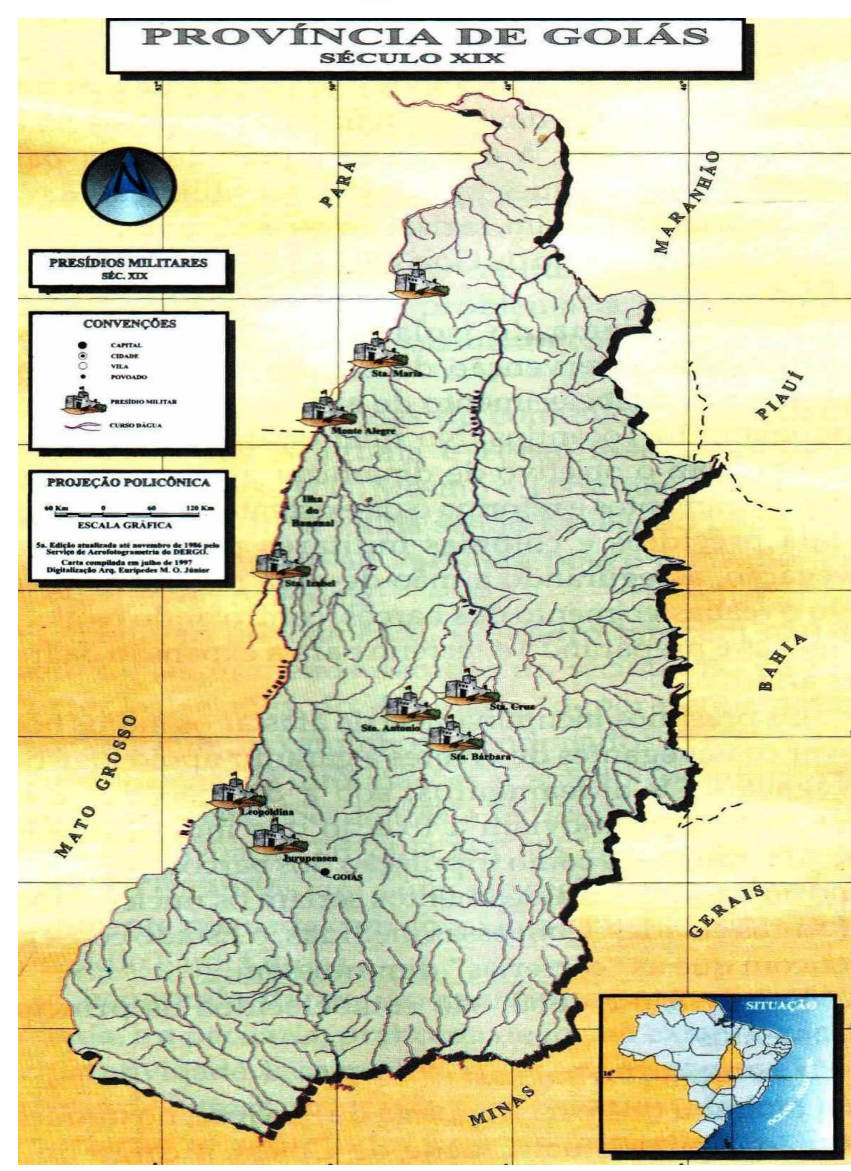

Figura 3. Mapa dos Presídios Militares do Século XIX. Fonte: Rocha, 1998.
Esses presídios militares serviram de portos de embarque e desembarque e comercialização de produtos que eram transportados para o norte do país. Eles tinham como objetivo proteger as fronteiras contra qualquer ameaça estrangeira e atender interesses políticos e militares. Depois da segunda metade do século XIX eles passaram a ser utilizados para intensificar a povoação as margens dos rios e auxiliar no desenvolvimento do comercio. Alguns dos presídios do vale do Araguaia, tais como o de Santa Leopoldina e Santa Maria, edificados as margens do rio, se tornaram os principais pontos de comércio e oficinas.

Após a inauguração da navegação a vapor a província goiana viveu prosperidades em todos os setores. Os povoados as margens do rio Araguaia cresceram e se expandiram. Segundo Carvalho (2008) "a implantação da companhia foi o elo propulsor na promoção do aumento do fluxo migratório e do desenvolvimento econômico dos presídios militares" (Carvalho, 2008; p.98). Por um período de dez anos a navegação a vapor do rio Araguaia viveu seu apogeu e os, os presídios militares serviram, de fato, de postos de embarque e entrepostos comerciais.

Nos primeiros anos do século XIX, com a política de implantação dos presídios militares na linha do rio Araguaia dava-se início ao processo de formação de cidades às margens do rio Araguaia. Dos sete presídios construídos as margens da linha do rio Araguaia o presídio de Santa Leopoldina, atual cidade de Aruanã-Go foi um dos principais no Estado de Goiás. Ele serviu de defesa do território e centro comercial da navegação a vapor do século XIX.

\section{0 Presidio de Santa Leopoldina nos relatórios da Província goiana}

Localizado na confluência do rio Vermelho com o Rio Araguaia e em cumprimento ao Aviso de 29 de Janeiro de 1849, do decreto do Ministério do Império foi criado em 1850, o presidio de Santa Leopoldina. Antes, porém, João Batista de Castro Morais Antas fez um estudo do vale rio Araguaia em que verificou ser as margens do rio o melhor lugar para a instalação dos presídios militares e para a nucleação dos gentios. Assim em obediência à Ordem Imperial de 29 de maio de 1849, nas proximidades da confluência do Rio Vermelho com o Rio Araguaia criou-se e construiu, em 1850, o Presidio Santa Leopoldina. Segundo Carvalho (2008, p.53) o presídio foi "implantado a margem direita do rio Araguaia, a um quilômetro e meio, mais ou menos, abaixo da junção do rio Vermelho com o rio Grande". Este presídio desde a sua criação desempenhou papel fundamental no auxílio da navegação a vapor no rio Araguaia.

Nos primeiros anos da sua existência o Presídio Militar Santa Leopoldina não atingiu os resultados esperados. Conforme Doles (1977, p. 438), " ali a população e as guarnições careciam de roupas, de armas e apresentava-se faminta". Em visita aos presídios militares de Santa Leopoldina e Santa Izabel, em 1852, o engenheiro João Batista de Castro Morais Antas elaborou um relatório ao governo da província em que afirmou que o estado em que os presídios se encontram era deplorável.

Se bem que $V$. Exa me não incumbisse de dar-lhe informações a cerca do estado em que se acham os Presídios ouso todavia occupar-me deste objecto não só porque tomo a peito a 
realização da navegação do Araguaya que esses estabelecimentos são destinados a proteger e auxiliar, como também porque tenho necessidade de justificar amplamente o que ja disse ao Exma Governo a respeito da fundação de novos Presidios. De mais: tudo quanto observei nos dois Presidios existentes deixou- me a conviccção profunda de que se se occultar a verdade ao governo e se por conseqüência não houver sobre estes estabelecimentos fiscalisação rigorosa, acompanhada de certas providencias que tomarei a liberdade de propôr, os presidies não passarão de inutil verba de despesa, não poderão prosperar e terá o Governo de retirar os destacamentos (Relatório do Dr. João Baptista de Castro Moraes Antas apresentado em 15 de março de 1852 acerca da exploração dos rios Tocantins e Araguaya, f. 11. Manuscrito da Biblioteca Nacional, Rio de Janeiro).

A respeito do Presídio de Santa Leopoldina o engenheiro Moraes Antas escreveu ao presidente da província afirmando que "no presidio não há nenhum desenvolvimento ou administração". No relatório entregue ao presidente da província, o engenheiro descreveu as instalações do presidio dizendo que "apresentavam-se elas em ruinas, morando o comandante no paiol, estando o quartel abandonado e servindo de curral" (Doles, 1977; p.438). Por meio deste relatório, Moraes Antas afirmou que o presidio não passava de "uma fazenda de pequena porção de gado, com todos os visos da negligência e do mau governo" (Relatório do Dr. João Baptista de Castro Moraes Antas de 15/03/1852). Para solucionar os problemas encontrados no presidio, João Batista de Castro Moraes Antas apresentou algumas sugestões para que o mesmo prosperasse. Sugeriu a troca imediata do comandante responsável pelo presídio de Santa Leopoldina e a implantação da agricultura para o auto abastecimento da população residente alegando que sem essa medida a navegação do rio Araguaia não se tornaria concreta. Sugeriu, também, a implantação da pecuária no presidio de Santa Leopoldina, visto que, [...]

[...] não ha talvez na provincia inteira uma região mais propria para a creação do gado vacum e cavallar que os campos da margem do Araguaya. Na Ilha do Bananal coberta de servos e veados de diversas qualidades, as pastarias se estendem desde a beira dos rios até as terras mais altas do interior que como o mais estão cobertos de mui boas mattas (Relatório do Dr. João Baptista de Castro Moraes Antas apresentado em 15 de março de 1852 acerca da exploração dos rios Tocantins e Araguaya, f. 18. Manuscrito da Biblioteca Nacional, Rio de Janeiro).

Em 1.853, o Presídio foi destruído pelos índios Karajás e reconstruído em 1.855 no local denominado Lago dos Tigre. No ano seguinte foi removido ao local de origem com o nome de Presídio Santa Leopoldina. De fato, nos relatórios dos anos seguintes apresentados aos presidentes da Província de Goiás constam que o presídio de Santa Leopoldina foi transferido para a margem direita do rio Araguaia abaixo da confluência do Rio Vermelho, pois não havia atingido as expectativas. A nova localização do presídio erigido em outubro de 1856 se encontrava em um trecho cujo embarque e desembarque se encontrava facilitado. Dr. João Bonifácio Gomes Siqueira no Relatório da presidência de 01/09/1857 relatou que "na margem direita do Araguaya abaixo da confluência do Rio Vermelho em um ponto assentado de 55 palmos de altura, d'uma e meia légua de extensão, e mais de meia de largura, com boa aguada, belas mattas e ricas pastagens: este ponto he sem dúvida o mais conveniente para porto de embarque".

Em nova instalação, o presidio de Santa Leopoldina prosperou atingindo em 1857 um povoado com três casas cobertas de telha, uma olaria, uma tenda de ferreiro e várias "casas de capim". A sede administrativa do presidio encontrava-se em construção, pois aguardava ainda a vinda de oito mil telhas do antigo presidio de Santa Leopoldina. Com o intuito de se estabelecer o contato com a capital da Província de Goiás, Villa Boa fora construída uma estrada terrestre que fez a ligação entre o presidio e a capital. 0 então presidente da província Dr. Francisco Januário ao apresentar o relatório a Assembleia Legislativa da Província, descreveu a situação do presidio de Santa Leopoldina em 1859 e enfatizou que "nenhum entre quaisquer outro presídio da província de Goiás havia prosperado quanto o presídio de Santa Leopoldina". Esta afirmação foi dada devido ao desempenho que o presidio Santa Leopoldina adquiriu em dois anos, triplicando o número de casas com telhas e outras instalações. Os produtos excedentes produzidos pelas roças estavam avaliados em $200 \$ 000$ réis ao que se pode verificar a prosperidade e acerto da mudança. 
Compoem-se o material de uma casa para a administração, um monjolo, uma officina de ferreiro, uma olaria, nove casas de telha e quatro de capim, feitas ultimamente para abrigo de diversas famílias, que ali acabão de mudar-se. Informa o inspector geral que há praças d'aquella guarnição, que já tem vendido sobras de mantimentos de suas roças particulares na sua importância de $200 \$ 000$ reis. (Trecho do Relatório da presidência - Dr. Francisco Januário da Gama Serqueira - em 1857).

Conforme os relatos do Dr. Francisco Januário de 1857 no presidio de Santa Leopoldina residia cerca de 60 pessoas, sendo 33 homens e 28 mulheres. A guarnição pertencente ao presidio era de 19 praças. Encontravam-se, também, neste presidio cerca de 100 cabeças de gado e oito cavalos adquiridos pelos moradores e praças. Essa característica fez com que os administradores da província cressem que o presidio de Santa Leopoldina se tornaria um grande entreposto comercial. Nos anos seguintes, o presidio militar se apresentou muito próspero. A população conseguia se manter farta em alimentos e as edificações sofreram mudanças no que se refere à ampliação dos espaços internos. No ano de 1861 ali se encontravam duas indústrias, uma relacionada à pecuária e outra a agricultura. 0 presidente da província de Goiás, José Martins Alencastre descreveu a indústria pastoril mostrando que a mesma tinha se prosperado nos últimos quatro anos. Relatou os animais com suas respectivas quantidades. "Gado vacum: da guarnição, 196 cabeças; dos particulares 52. Gado cavallar: da guarnição, 20 cabeças; dos particulares 12. Gado suíno: 80 cabeças" (Relatório de José Martins Alencastre, 1861, p.25).

Observamos nos relatórios da província grande preocupação por parte dos presidentes quanto a insalubridade do local onde o presido Santa Leopoldina fora erigido. Consta, também, um grande esforço para sanar este problema. No Relatório da Presidência de 1862, Dr. José Martins Pereira de Alencastre enfatizou "como todos os povoados que parão as margens dos nossos grandes caudaes, S. Leopoldina tem poucas questões de salubridade, mas para o futuro pode este estado pouco salubre melhorar com a aclimatação dos habitantes, e melhoramento das condições egyenicas". Mas a questão da insalubridade não foi solucionada até o início do século XX, mas, também, não atrapalhou o presidio enquanto auxiliador da navegação a vapor no Araguaia e nem mesmo quanto núcleo de povoamento. Pelo contrário encontramos em vários relatórios da província de Goiás uma apregoada prosperidade do presidio Santa Leopoldina. A navegação a vapor do rio Araguaia naquele momento se encontrava no seu apogeu. A catequização dos indígenas situados próximos ao presidio de Santa Leopoldina tinha o objetivo de evitar que os mesmos atrapalhassem a navegação a vapor do rio Araguaia e, também, o funcionamento dos presídios.

Temerosos, mas atentos a qualquer investida indígena construiu próximo ao presidio o Colégio Izabel para auxiliar na catequização dos gentios. O Colégio |foi fundado em janeiro de 1871 por Couto Magalhães com o auxílio dos missionários capuchinhos. "O propósito do Colégio era o de impor uma nova educação às crianças indígenas, preservando, ao mesmo tempo, as línguas de suas tribos para que servissem de mediadores quando reintroduzidos em suas tribos de origem". (Marin, 2009; p. 155). Nos anos de 1873 o Colégio Isabel contava com cerca de 32 alunos de ambos os sexos, cujo as etnias pertenciam aos Karajá, Kayapós e outras. Os indígenas recebiam instruções primárias religiosas e profissionais.

O Governo Imperial atendendo mais a conveniência de ensaiar com melhor sistema a catequese e civilização dos índios, criou, sob a denominação de-Colégio Isabel- na localidade mais apropriada do Vale do Rio Araguaia, um estabelecimento onde os meninos das diversas tribos daquelas regiões recebam os elementos da instrução primária, religiosa e profissional [...] O Colégio Isabel já funciona provisoriamente em uma casa do Presídio Leopoldina, local escolhido para sua efectiva fundação pelo referido Dr. Couto de Magalhães (Memórias Goianas 11, 1999, p. 78).

Não tardou para que o funcionamento do colégio se deparasse com diversos problemas. 0 ensino rígido e maus tratos sofridos pelos alunos indígenas se tornara divergente com a cultura indígena. Tal problema estava presente na relação do índio com os costumes dos colonos dificultando a sua adaptação a sociedade apesar de serem vistos como semicivilizados após o processo de catequização. Segundo Baldus (1970) Ehreinreich ao viajar pelo Araguaia em 1888 percebeu as negligências que o colégio apresentava. Relatou suas impressões dizendo que, [...] 
[...] o diretor tratava os índios como escravos, mandando-os trabalhar para ele. Desamparados eles estavam entregues as brutalidades de e dos amigos dele. As moças estavam a mercê dos instintos de todos esses opressores. A maioria delas já haviam dado a luz o filho ou aguardava o momento. Havia muito tempo que não chegavam índios novos, pois as violências dos civilizadores brancos afugentavam os selvagens cada vez mais. A maior parte dos índios do colégio já tinha chegado aos trinta anos, mas nenhum deles pensava em ir-se. Há tanto tempo acostumados a servidão e tutela, continuavam a fazer seus serviços, com indolência estupida. Naturalmente não se cogitava mais do ensino (Baldus, 1970, p.44).

Contudo o colégio ainda se manteve aproximadamente até meados da década seguinte. Alguns alunos do Colégio Isabel se tornaram intérprete, cuja função era mediar a comunicação entre os indígenas e colonos. Dr. Couto Magalhães se mostrou preocupado com o funcionamento do colégio Izabel apontando alguns caminhos para que se mantivesse em "pé" e no firme propósito de civilizar os índios.

Passados cinco anos de funcionamento do Colégio Isabel, os objetivos de civilizar índios e transformá-los em bons marinheiros, mecânicos, carpinteiros e ferreiros não haviam sido alcançados. Fracassados os primeiros ensaios, Couto de Magalhães deu uma nova orientação ao Colégio Isabel. Se os alunos não tinham demonstrado interesse naqueles ofícios, o diretor acreditava que poderiam tornar-se bons criadores de gado (Marin, 2009, p. 158).

Com a finalidade de alcançar tal objetivo propuseram a transferência do Colégio Izabel para a fazenda Dumbazinho, a seis quilômetros de Santa Leopoldina. Segundo Marin (2009) esta fazenda tinha terras adequadas "à pecuária, porque havia extensas planícies de pastagens nativas" (Marin, 2009; p.159). Couto Magalhães acreditava que a pecuária traria um crescimento populacional para a fazenda, até então pouco habitada, melhorando a economia e, consequentemente traria um bom crescimento à região do presídio Santa Leopoldina. Contudo, tais medidas não solucionaram os problemas existentes no presidio. Problemas frequentes relacionados à venda de crianças indígenas somados a falta de pagamento dos professores e trabalhadores e os relatos de abusos sexuais e físicos cometidos pelos colonos fizeram com que os presidentes da província decidissem fechar as portas do colégio. Segundo Marin (2009, p. 159) "nos últimos anos de existência do Colégio Isabel, as crianças ficaram praticamente abandonadas, sem receber adequadamente alimentação, vestuário e medicação". Destarte, o governo da província de Goyaz recomendou que "exonerassem seus funcionários, extinguissem a Fazenda Dumbazinho, vendessem o rebanho de bovinos e liquidassem o restante do patrimônio, como forma de contenção de gastos de recursos públicos" (Marin, 2009 , p. 161). Cumpridas as recomendações, no dia dez de novembro de 1889, o Colégio Isabel fechou suas portas.

Apesar de todos estes problemas o presídio Santa Leopoldina continuou em pleno funcionamento. Em meados dos anos de 1870 o presidio de Santa Leopoldina se tornara centro de todo e qualquer serviço ligado à navegação a vapor do rio Araguaia. Era, também, entreposto comercial entre a província de Goyaz e a do Pará. Até o final da década de 1870 atingia seus objetivos auxiliando na navegação a vapor no rio Araguaia como entreposto comercial e sendo ponto de embarque e desembarque tanto de pessoas como de produtos vindos de outras províncias. Mesmo com as dificuldades da navegação a vapor no rio Araguaia, o presidio de Santa Leopoldina manteve suas funções como posto de embarque e desembarque de produtos. Serviu como um dos maiores centros que auxiliaram a navegação a vapor. A sede da companhia a vapor se encontrava fixada na área do presidio. Auxiliou no povoamento as margens do rio Araguaia e, também, na catequização dos índios. Devemos ressaltar que em consequência à navegação a vapor para outros Estados acelerou a povoação da região, e, consequentemente, crescia a população no Presídio Santa Leopoldina. "A população que sobe hoje a mais de 300 pessoas vai argumentando progressivamente por ser o centro de todo o serviço relativo à navegação do Araguaya e o interposto do commercio desta capital com o Pará" (Memórias Goianas 11, 1996; p. 19). Ocorre que devido à navegação "muitas pessoas vieram morar na região, e em pouco tempo, suas ruas aumentaram e já existiam várias casas de comércio, uma igreja e uma escola" (Carvalho, 2008, p. 54). Os moradores trabalhavam nas roças, lavouras e pastos garantindo sua subsistência.

O então presidente da província, Sr. Dr. Aristides de Souza Spindola (1880) comunicou por meio de relatório à Assembleia Provincial de Goyaz que o Ministério da Guerra havia extinguido o 
presídio de Santa Leopoldina. "Por aviso de 10 de março último comunicou-me o ministério da Guerra que ficava extincto este presidio, devendo ser recolhido à capital o pessoal e material pertencente ao mesmo ministério; [...] em vista da importância da localidade, determinei que ali ficasse estacionado um destacamento militar [...]" (Memorias Goianas 12, 1999, p. 274).

Com a extinção do presidio Santa Leopoldina e da Fazenda Dumbazinho se formou no local um pequeno povoado que logo prosperou. E assim do presídio militar Santa Leopoldina se dava início a um povoado que pela Lei Provincial no 548, de 02/08/1875, ganhou foros de Distrito com a denominação de Santa Leopoldina, subordinado ao município de Goiás. Em consequência da navegação vapor a povoação ganhou impulso alcançando a categoria de Vila que em homenagem ao presídio ganhou a denominação de Leopoldina. A população da Vila Leopoldina se constituiu das gerações de famílias que habitavam o presidio de Santa Leopoldina, assim como um número crescente de indígenas. Segundo os moradores da cidade de Aruanã "nas primeiras décadas do século XX a população da Aldeia Buridina teria crescido expressivamente devido aos indígenas que migraram da Ilha do Bananal para Leopoldina atraída pela prosperidade da aldeia" (Portela; 2006, p 70). Alguns viajantes que estiveram presentes na Vila Leopoldina na década de 20 ressaltaram a figura de um indivíduo, conhecido como Coronel Santana. Segundo Portela (2006) "mesmo na pequena população de Leopoldina era concebido como um líder ou mesmo "chefe". Se tratava de grande conhecedor dos caminhos fluviais da região ao qual cabia decidir se o migrante ali chegado era bem-vindo ou não".

Este local possuía uma pequena população, pertencente praticamente à mesma família, liderados por um chefe conhecido como Coronel Santana que recepcionava todos os que chegavam ao local, aprovando ou não a presença do chegante. Os moradores mais antigos da cidade de Aruanã e da Aldeia Buridina se referem ao grande respeito exercido por esta liderança, descrevendo-o como um homem alto e negro que tinha grande conhecimento dos caminhos fluviais da região. Provavelmente, sua presença neste local foi decorrente do trabalho na navegação fluvial (Portela, 2006, p 72).

Parafraseando Portela (2006) o descaso dos governantes para com os indígenas e o crescimento econômico acentuado do povoado de Leopoldina fez com que a aldeia Buridina crescesse. A aldeia Buridina é composta por indígenas da etnia Karajás, "era uma pequena população pertencente a uma mesma parentela" segundo Rocha (2008, p. 124). Portela (2006) na sua dissertação de mestrado intitulada "Nem Ressurgidos, Nem Emergentes: a Resistência Histórica dos Karajás de Buridina em Aruanã-Go (1980-2006), mencionou o etnólogo Krause que em 1943 detectou a presença da aldeia Buridina localizada na confluência entre dois rios, Vermelho e o Araguaia. A aldeia Buridina foi fundada por volta de 1903, segundo Rocha (2008). Outra liderança bastante conhecida e respeitada na cidade de Aruanã foi relatada por Artiaga (1948) em sua viagem pelo rio Araguaia na década de 1940. Trata-se do cacique Kapitxana de uma das maiores aldeias Karajá. Artiaga afirma que, [...]

[...] a situação piorou com a morte do velho Kapitxana que exercia poder benéfico sobre a tribo, mantendo a paz durante anos e protegendo-a com sabedoria. Kapitxana tinha conseguido melhorar muito a moral e trazer a ordem garantida, fixar a permanência de sua gente nos vales saudáveis e abundantes do alto rio, o que não acontece com as tribos Craôs que têm de concorrer com o cristão, puxando o machado para exploradores do suor humano a troco de pratos de feijão (Artiaga, 1948, p. 66).

Na divisão administrativa referente ao ano de 1911, o Distrito figura no município de Goiás. Teve seu nome alterado de Santa Leopoldina para Leopoldina em 1920. Nos quadros de apuração do recenseamento geral de 01-09-1920, o Distrito aparece com a denominação de Leopoldina. Assim permanecendo em divisões territoriais datadas de 31-12-1936 e 31-12-1937. A Vila passou à condição de distrito de Goiás, por volta de 1939, integrando o Município de Goiás. Situação em que permaneceu até 18 de dezembro de 1958 quando teve novamente sua nomenclatura alterada de Leopoldina para Aruanã pelo decreto-lei estadual no 8305, de 31-12-1943. Na divisão territorial de 01-07-1950, o distrito já denominado Aruanã ainda figura no município de Goiás. Assim permanecendo na divisão territorial datada de 01-07-1955. Crescendo rapidamente com a ligação por rodovia e, principalmente, com impulso econômico gerado pelo incipiente, mas frequente "turismo" das/nas águas araguaias tornou-se logo um município autônomo. Pela lei estadual no 2427 , de 
18-12-1958 o distrito de Aruanã foi elevado à categoria de município desmembrado da cidade de Goiás com a mesma denominação da toponímia indígena. Foi instalado oficialmente em 1o de janeiro de 1959. 0 então Governador de Goiás, José Feliciano Ferreira foi quem concedeu emancipação a Vila Leopoldina. Em divisão territorial datada de 01-07-1960, o município ficou constituído do distrito sede, ou seja, cidade de Aruanã.

Como já disse, seu nome advém do lendário peixe Aruanã o qual ilustra o brasão do município. 0 município de Aruanã possui densa drenagem formada por cursos d'água predominantemente perene, que constitui nesta área a bacia hidrográfica do Rio Araguaia. Seus principais afluentes são os rios Vermelho e do Peixe, os ribeirões Pinguela e da Estiva e os córregos da Voadeira, do Garrafão, Dois Irmãos e do Esgotão. No município há a formação de diversos lagos e lagoas propiciadas pelos terrenos baixos da planície do Araguaia. É caracterizado pelo clima tropical úmido. Possui duas estações bem definidas, a da seca e a chuvosa, com chuvas regulares no período de outubro a março. A cobertura vegetal é constituída na sua maior parte por cerrados e campos que cede lugar às lavouras e pastagens. Há, ainda, a existência de matas ciliares com área de solo bastante fértil.

A cidade de Aruanã está localizada na confluência do Rio Vermelho com o Rio Araguaia no mesmo lugar do Presídio Santa Leopoldina. Surgiu sem planejamento. Sua história populacional está marcada pela presença dos índios, principalmente dos Karajás e pela migração de pessoas de todos os quadrantes do país que para suas terras se dirigiam em razão da pesca. 0 comércio local era feito através das vias fluviais com a utilização de barcos a motor e canoas que vinham de outras regiões negociar. A cidade de Aruanã surgiu, portanto, do presidio militar de Santa Leopoldina, as margens do rio Araguaia. É marcada pela presença dos índios Karajás e da população remanescente do presídio de Santa Leopoldina. Numa palavra, se o intuído dos presidentes da província do século XIX era promover o povoamento de Goiás, tal política se mostrou eficaz no presidio de Santa Leopoldina.

\section{Referências}

Alencastre, J. M. P. de (1863). Anais da Província de Goiás, 1863. Brasília: Editora Gráfica Ipiranga.

Agência Nacional de Transportes Aquaviários. (2013). Bacia do Tocantins-Araguaia. Recuperado em 10 jan. 2017 de: http://www.antaq.gov.br/portal/PNIH/BaciaTocantinsAraguaia.pdf

Baldus, H. (1970). Tapirapé: tribo Tupi no Brasil Central. São Paulo: Nacional.

Borges, D. R. (2010). Rio Araguaia - corpo e alma. São Paulo: IBRASA.

Carvalho, F. L. (2008). Nas águas do Araguaia: A navegação e a hibridez cultural. Goiânia: Dissertação de Mestrado [História Cultural], Pontifícia Universidade Católica de Goiás, Goiânia, GO, Brasil.

Carvalho, F. L. (2010). Fronteiras e conquistas pelo Araguaia - século XIX (2a. ed.). Goiânia: KELPS.

Castoriadis, C. (1987). As encruzilhadas do labirinto (2. Os domínios do Homem). Rio de Janeiro: Paz e Terra.

Chartier, R. (1991). 0 Mundo como Representação. Estudos Avançados, 5 (11) [USP, São Paulo]. Recuperado em 15 jan. 2017 de: http://www.revistas.usp.br/eav/article/view/8601/10152

Doles, D. E. M. (1971). A Ligação Centro-Norte pela via Araguaia-Tocantins no Período Colonial. Anais do V Simpósio Nacional dos Professores Universitários de História - ANPUH, São Paulo. Recuperado em 18 jan. 2017 de http://anais.anpuh.org/wp-content/uploads/mp/pdf/ANPUH.S05.14.pdf

Doles, D. E. M. (1973). As Comunicações Fluviais pelo Tocantins e Araguaiano Século XIX. Goiânia: Editora Oriente.

Doles, D. E. M. (1977). Uma visão de Goiás através de Moraes Antas. Revista de História, 112 [USP, São Paulo]. Recuperado em 17 jan. 2017 de: http://www.revistas.usp.br/revhistoria/article/view/62245/65072

(C) Labor \& Engenho, Campinas [SP] Brasil, v.11, n.2, p.146-164, abr./jun. 2017. 
Eiten, G. (1994). Vegetação do Cerrado. In M. N. Pinto (Coord.) Cerrado: caracterização, ocupação e perspectivas (pp.1-65). Brasília: UnB; SEMATEC.

Fuente, H. de la. (2007). Margens do rio Araguaia. Recuperado em 19 jan. 2017 de http://www.recantodasletras.com.br/cordel/741375.

Hesse, H. (1985). Sidartta. Rio de Janeiro: Record.

Marin, J. O. B. (2009). A formação de trabalhadores brasileiros: a experiência do Colégio Isabel. História Usininos, 13 (2) [Rio Grande do Sul, mai./ago.]. http://revistas.unisinos.br/index.php/historia/article/view/5084.

Memórias Goianas 5 (1996). Relatórios políticos, administrativos, econômicos, sociais, etc. dos governos da província de Goiás. Goiânia: UCG.

Memórias Goianas 8 (1999). Relatórios políticos, administrativos, econômicos, sociais, etc. dos governos da província de Goiás. Goiânia: UCG.

Memórias Goianas 11 (1999). Relatórios políticos, administrativos, econômicos, sociais, etc. dos governos da província de Goiás. Goiânia: UCG.

Memórias Goianas 12 (1999). Relatórios políticos, administrativos, econômicos, sociais, etc. dos governos da província de Goiás. Goiânia: UCG.

Oliveira, M. de F. (2008). Cidades Ribeirinhas do Rio Tocantins: identidades e fronteiras. Tese de Doutorado [História], Universidade Federal de Goiás, Goiânia, GO, Brasil.

Palacín, L., \& Moraes, M. A. S. (1989). História de Goiás (1722-1972) (5a. ed.). Goiânia: Ed. UCG.

Portela, C. A. (2006). Nem ressurgidos, nem emergentes: a resistência histórica dos Karajás de Buridina em Aruanã - GO (1980-2006). Dissertação de Mestrado [História], Universidade Federal de Goiás, Goiânia, GO, Brasil.

Ratzel, F. (1982/1898). O solo, a sociedade e o estado (M. A. Eufrásio, Trad.). São Paulo: FFLCH-USP. [Título original: Le sol, le societé et el'etat. 1898].

Rocha, L. M. (1998). O Estado e os Índios: Goiás, 1850-1889. Goiânia: Ed. UFG.

Rocha, L. M. (2008). Aruanã-GO: identidades e fronteiras étnicas no rio Araguaia. Revista Mosaico, 1 (2), 123-132 [Goiânia, jul./dez.].

Souza, M. J. L. de (1995). 0 território: sobre espaço e poder, autonomia e desenvolvimento. In Castro, I. E. de. et al. Geografia: conceitos e temas (pp.77-116). Rio de Janeiro: Ed. Bertrand Brasil.

\subsection{Relatórios dos Governos da Província de Goiás}

Relatório com que o EXM. Sr Doutor Manoel de Araújo e Mello passou a administração da Província ao seu sucessor, o Exm. Sr. José Martins Pereira de Alencastre, no dia 22 de abril de 1861. Rio de Janeiro, 1861. Memorias Goianas 8, 1997.

Relatório apresentado à Assembléa Legislativa Provincial de Goyaz na Sessão Ordinária de 1861 pelo Exmº . Presidente da província José Martins Pereira Alencastre. Memorias Goianas 9, 1998.

Relatório do Exmo. Sr. Desembargador João Bonifácio Gomes de Siqueira, 1o Vice - Presidente da Província de Goiaz, na abertura da Assembleia Legislativa da mesma Província, no dia 1o de setembro de 1868. Goiaz - Typographia Provincial - 1870. Memorias Goianas 10, 1998.

Relatório que à assembleia Legislativa de Goiaz apresentou na sessão ordinária de 1852 o Exmº. Presidente da província Doutor Antônio Joaquim da Silva Gomes. Memorias Goianas 5, 1996. 
Relatório do Dr. João Baptista de Castro Moraes Antas apresentado em 15 de março de 1852 acerca da exploração dos rios Tocantins e Araguaya, f. 11. Manuscrito da Biblioteca Nacional, Rio de Janeiro. Digitalizado.

Relatório que o Exmº. Sr. Vice Presidente João Bonifácio Gomes de Siqueira apresentou no acto de passar-lhe a administração da Província de Goiaz, o Exm. Sr. Doutor Antônio Augusto Pereira da Cunha. Memorias Goianas 7, 1997.

Relatório que o Exm. Sr. Vice-Presidente João Bonifácio Gomes de Siqueira entregou á Presidência da mesma ao o Exmo. Sr. Dr. Francisco Januário da Gama Cerqueira. Memorias Goianas 7, 1997.

Relatório apresentado à Assembleia Legislativa Provincial de Goiaz, na sessão ordinário de 1859 pelo Exmº . Presidente Dr. Francisco Januário da Gama Cerqueira. Memorias Goianas 7, 1997.

Relatório apresentado à Assembléa Legislativa Provincial de Goiaz na Sessão Ordinária de 1861 pelo Exmo Presidente da província José Pereira de Alencastre. Memorias Goianas 9, 1998.

Relatório Lido na Abertura d'Assembléa Legislativa de Goyaz pelo Exmº. Sr. José Martins Pereira de Alencastre. Memorias Goianas 9, 1998. 